\title{
Chronic oral administration of rhamnogalacturonan-II dimer, a pectic polysaccharide, failed to accelerate body lead detoxification after chronic lead exposure in rats
}

\author{
Maha Tahiri ${ }^{1}$, Jean Claude Tressol ${ }^{1}$, Thierry Doco ${ }^{2}$, Yves Rayssiguier ${ }^{1}$ and Charles Coudray ${ }^{1 *}$ \\ ${ }^{1}$ Centre de Recherche en Nutrition Humaine d'Auvergne CRNH, Unité Maladies Métaboliques et Micronutriments, INRA, \\ Centre de Clermont-Ferrand/Theix, 63122, Saint Genès Champanelle, France \\ ${ }^{2}$ Institut des Produits de la Vigne, Unité de Recherches Biopolymères et Arômes, INRA Montpellier, 2, place Viala, 34060 \\ Montpellier Cedex, France
}

(Received 26 March 2001 - Revised 23 July 2001 - Accepted 25 August 2001)

\begin{abstract}
Lead is a ubiquitous heavy metal and its toxicity remains an important public health issue. In previous work, we reported that ingestion of rhamnogalacturonan-II dimer (dRGII), a pectic polysaccharide, may decrease intestinal absorption and status of $\mathrm{Pb}$ in rats. Here, we evaluated the potential detoxifying effect of different doses of dRGII after chronic oral $\mathrm{Pb}$ exposure in rats. For this purpose, six groups of ten male Wistar rats weighing $150 \mathrm{~g}$ were treated as follows: group A received a semi-purified control diet for 6 weeks; groups B, C, D, E and F received the same diet plus $3 \mathrm{mg} \mathrm{Pb}$ (as acetate) for 3 weeks. Group B was then killed. Groups $\mathrm{C}, \mathrm{D}, \mathrm{E}$, and $\mathrm{F}$ continued to receive the semi-purified control diet containing $0,2,6$ or $18 \mathrm{~g}$ $\mathrm{dRGII} / \mathrm{kg}$ diet for 3 additional weeks. During the last $5 \mathrm{~d}$, a Pb conventional balance study was performed. Rats were then anaesthetized and tissues were sampled for $\mathrm{Pb}$ and essential minerals assay. The results showed that residual $\mathrm{Pb}$ in the added dRGII was not available for absorption. However, the added dRGII failed to induce any significant increase in faecal or urinary $\mathrm{Pb}$ excretion. Consequently, at the end of the study the intestinal $\mathrm{Pb}$ absorption and balance remained unchanged in the animals receiving the different doses of dRGII. In line with this, we showed that dRGII administration was not effective in decreasing tibia or kidney $\mathrm{Pb}$ levels in rats. In conclusion, $\mathrm{Pb}$ complexed by dRGII in fruits and vegetables and fruit juice is thus mostly unavailable for intestinal absorption. However, the addition of dRGII after chronic $\mathrm{Pb}$ exposure does not help $\mathrm{Pb}$ detoxification.
\end{abstract}

Rhamnogalacturonan-II: Lead absorption: Lead detoxification: Rat

Lead is a ubiquitous and heavy metal, and its toxicity remains an important public health issue (Silbergeld, 1996; Markowitz, 2000). Some of the chelating agents used in $\mathrm{Pb}$ detoxification therapy are known to have adverse effects and to promote losses of essential cations (Thomas \& Chisolm, 1986; Chisolm, 2000). The search for more specific and safer agents for the prevention and treatment of $\mathrm{Pb}$ poisoning is thus still justified.

Since the 1970s, the metal-binding capacities of some pectin cell-wall polysaccharides have been investigated in an attempt to use their metal-binding properties in the detoxification of heavy metals such as $\mathrm{Pb}$ and $\mathrm{Cd}$ (Niculescu et al. 1968; Rose \& Quarterman, 1987). Most of the reported work on the action of pectin on $\mathrm{Pb}$ poisoning has shown that $\mathrm{Pb}$ absorption and status in rats are lowered by adding pectin to the experimental diets (Bondarev et al. 1979; Kushneva \& Koltunova, 1997).

Recently, rhamnogalacturonan-II dimer (dRGII) has been isolated and characterized from apples and wine (Pellerin et al. 1996). dRGII is a complex pectic polysaccharide present in fruits and vegetables and also in fruit juices and wine. In vitro studies have shown that dRGII forms coordination complexes with di- and trivalent cations. The chelation of cations by dRGII is very specific; it binds $\mathrm{Pb}^{2+}$, $\mathrm{Sr}^{2+}$, and $\mathrm{Ba}^{2+}$ but not essential cations such as $\mathrm{Mg}^{2+}, \mathrm{Zn}^{2+}$, $\mathrm{Fe}^{2+}$ and $\mathrm{Fe}^{3+}$. In our previous work (Tahiri et al. 2000), we showed that $\mathrm{Pb}$ was less bioavailable from the complex $\mathrm{Pb}-$ dRGII than from $\mathrm{Pb}$ acetate. We have also shown that the addition of unleaded dRGII to their diet helped further decrease $\mathrm{Pb}$ absorption and burden in rats. These data

Abbreviation: dRGII, rhamnogalacturonan-II dimer.

* Corresponding author: Dr Charles Coudray, fax +334 736246 38, email coudray@clermont.inra.fr 
strongly suggest a potential detoxifying effect of dRGII, probably through chelation of dietary and endogenous $\mathrm{Pb}$ in the gastrointestinal tract. The aim of the present study was therefore to evaluate the potential detoxifying effect of different doses of dRGII after chronic $\mathrm{Pb}$ exposure in rats.

\section{Materials and methods \\ Reagents and equipment}

Suprapure $\mathrm{HNO}_{3}$ and $\mathrm{H}_{2} \mathrm{O}_{2}$ were purchased from Merck (Darmstadt, Germany) and $\mathrm{Pb}$ acetate was purchased from Sigma Chemical Co. (St Louis, MO). All other chemicals were of the highest quality available. Distilled water was used throughout. An inductive coupled plasma mass spectrometer (Plasmaquad II system; Fisons Instruments; Manchester) with a Meinhard nebulizer was used for the $\mathrm{Pb}$ assay and a Perkin Elmer AA800 spectrometer (Perkin Elmer, St-Quentin en Yvelines, France) for the $\mathrm{Ca}, \mathrm{Mg}, \mathrm{Fe}$, $\mathrm{Zn}$ and $\mathrm{Cu}$ assays.

\section{Rhamnogalacturonan-II dimer preparation}

dRGII was prepared from an industrial apple residue (Les Vergers de Chateaubourg, 35220 Chateaubourg, France). Apple residue was treated for $3 \mathrm{~d}$ with pectinolytic enzymes (Rapidase $\mathrm{Liq}^{+}, 0.08 \%$ (v/v); Gist-Brocades, Seclin, France). The supernatant fraction was filtered and concentrated, and then injected on a DEAE-Fractogel $650 \mathrm{M}$ column $(18 \times 25 \mathrm{~cm}$; Pharmacia $)$ equilibrated at $150 \mathrm{ml} / \mathrm{min}$ with $30 \mathrm{mmol}$ acetate buffer $/ \mathrm{l}, \mathrm{pH} 5$. The dRGII purified fraction was obtained by washing the column with $200 \mathrm{mmol} \mathrm{NaCl} / \mathrm{l}$ in $30 \mathrm{mmol}$ buffer acetate/l, pH 5. The purified dRGII was then injected on a Superdex $75 \mathrm{HR}$ column and the glycosyl residue composition was determined (Pellerin et al. 1996) to verify the homogeneity of the fraction. The structure of dRGII is shown in Fig. 1.

\section{Animals and diets}

Male Wistar rats weighing $150 \mathrm{~g}$ from the laboratory animal facility of the National Institute of Agronomic Research (INRA de Clermont-Ferrand Theix) were used. They were housed under conditions of constant temperature (20$22^{\circ} \mathrm{C}$ ), and humidity $(45-50 \%)$ in rooms with a fixed 12 -h artificial light-dark cycle. The rats were cared for according to the guidelines of the European Community for the use of experimental animals (L358-86/609/EEC). All the rats were first adapted using a semi-purified diet for $7 \mathrm{~d}$. The diet used was that recommended by the Ad Hoc Committee on Standards for Nutritional Studies in Animals (Reeves $e t$ al. 1993). Its composition is given in Table 1. Measured dietary levels of $\mathrm{Ca}, \mathrm{Mg}, \mathrm{Fe}, \mathrm{Zn}$ and $\mathrm{Cu}$ in this diet were 5540, 540, $39 \cdot 8,43 \cdot 1$ and $6 \cdot 6 \mathrm{mg} / \mathrm{kg}$ dry weight, respectively. After the adaptation period, the sixty rats were randomized into six groups. These groups comprised a control group (group A) receiving the control diet, and five groups receiving $3 \mathrm{mg}$ $\mathrm{Pb} / \mathrm{kg}$ diet as $\mathrm{Pb}$ acetate for 3 weeks. After these 3 weeks, $\mathrm{Pb}$ addition was stopped. One group of ten $\mathrm{Pb}$-treated animals (group B) was killed to serve as a baseline for $\mathrm{Pb}$ status. The control group continued to receive the semi-purified control diet for 3 additional weeks. The four leaded groups (groups $\mathrm{C}, \mathrm{D}, \mathrm{E}$ and $\mathrm{F}$ ) received rations supplemented with one of the following doses of dRGII: $0,2,6$ or $18 \mathrm{~g} / \mathrm{kg}$ diet respectively for 3 additional weeks. During the last $5 \mathrm{~d}$ of the experimental period the rats were placed in individual

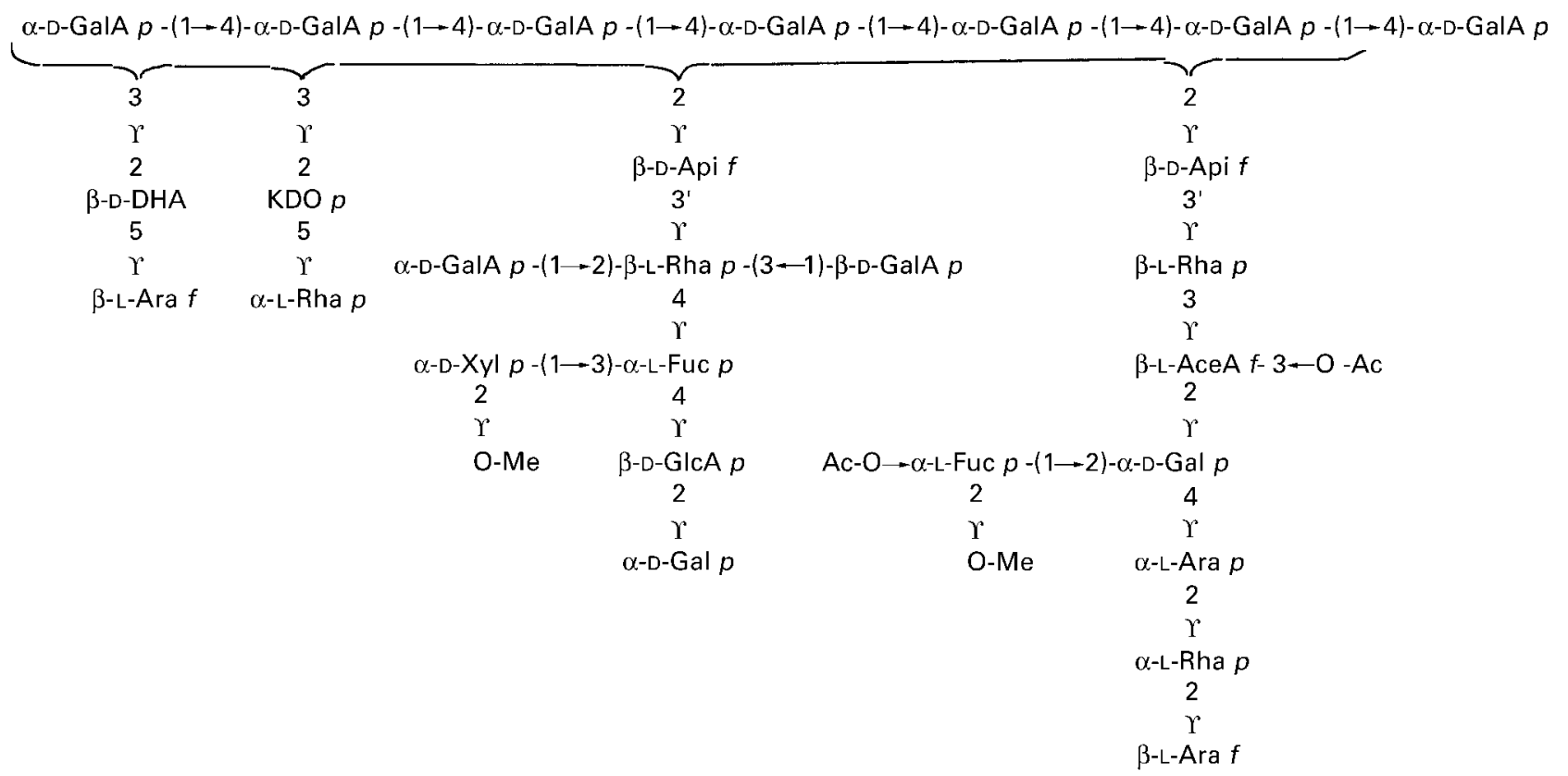

Fig. 1. Structure of the rhamnogalacturonan-II monomer. The four oligoglycoside side chains $A-D$ are shown whose residues are numbered according to the model sequence. 2-O-Me- $\alpha$-L-Fuc $p, 2-O-$ methyl- $\alpha$-L-fucopyranose; $\alpha$-L-Rha $p, \alpha$-L-rhamnopyranose; $\alpha$-L-Fuc $p, \alpha-L-f u c o-$ pyranose; 2-O-Me- $\alpha$-D-Xyl $p, 2-O-$-methyl- $\alpha$-D-xylopyranose; $\alpha$-L-Ara $p, \alpha$-L-arabinopyranose; $\beta$-L-Ara $f$, $\beta$-L-arabinofuranose; $\beta$-D-Api $f$, $\beta$-D-apiofuranose; $\alpha$-D-Gal $p, \alpha$-D-galactopyranose; $\alpha$-D-GalA $p, \alpha$-D-galacturonic acid; $\beta$-D-GlcA $p, \beta$-D-glucuronic acid; KDO, 3-deoxyD-manno-octulosonic acid; $\beta$-D-DHA, 3-deoxy-D-lyxo-heptulosaric acid; $\beta$-L-AceA, $\beta$-L-aceric acid. 
Table 1. Composition of the experimental diets ${ }^{\star}$

\begin{tabular}{|c|c|c|c|c|c|}
\hline Groups... & Control & Pb-treated & $\begin{array}{l}\text { Pb-treated }+2 \mathrm{~g} \\
\mathrm{dRG} / 1 / \mathrm{kg} \text { diet }\end{array}$ & $\begin{array}{l}\text { Pb-treated + } 6 \mathrm{~g} \\
\mathrm{dRGII} / \mathrm{kg} \text { diet }\end{array}$ & $\begin{array}{c}\text { Pb-treated }+18 \mathrm{~g} \\
\mathrm{dRG} / \mathrm{g} / \mathrm{kg} \text { diet }\end{array}$ \\
\hline \multicolumn{6}{|l|}{ Diet ingredients (g/kg DM) } \\
\hline Casein hydrolysate acid & 200 & 200 & 200 & 200 & 200 \\
\hline Wheat starch & 650 & 650 & 650 & 650 & 650 \\
\hline Maize oil & 50 & 50 & 50 & 50 & 50 \\
\hline Alphacel, non-nutritive bulk & 50 & 50 & 50 & 50 & 50 \\
\hline DL-Methionine & 3 & 3 & 3 & 3 & 3 \\
\hline Choline bitartrate & 2 & 2 & 2 & 2 & 2 \\
\hline AIN salt mix $†$ & 35 & 35 & 35 & 35 & 35 \\
\hline AIN vitamin mix $\ddagger$ & 10 & 10 & 10 & 10 & 10 \\
\hline dRGII (g/kg diet) & 0 & 0 & 2 & 6 & 18 \\
\hline
\end{tabular}

dRGII, rhamnogalacturonan-II dimer.

* Powdered diet $(100 \mathrm{~g})$ was mixed daily with $100 \mathrm{ml}$ deionized water to form a semi-liquid food prepared on site.

†AIN salt mixture (g/kg mixture): calcium phosphate dibasic 500; sodium chloride 74; potassium citrate monohydrate 220; potassium sulfate 52; magnesium oxide 24; manganese carbonate ( $43-48 \% \mathrm{Mn}) 3 \cdot 5$; ferric sulfate (16-17\% Fe) 6; zinc carbonate $(70 \% \mathrm{ZnO}) 1 \cdot 6$; copper carbonate $(53-55 \% \mathrm{Cu}) 0.3$; potassium iodate 0.01 ; sodium selenite 0.01 ; chromium potassium sulfate 0.55 ; sucrose, finely powedered 118 .

¥ AIN vitamin mixture (mg/kg mixture): thiamine hydrochloride 600; riboflavin 600; pyridoxine hydrochloride 700; nicotinic acid 3000; D-calcium pantothenate 1600; folic acid 200; D-biotin 20; cyanocobalamin (vitamin $\mathrm{B}_{12}$ ) 1; retinyl palmitate (Vitamin A) pre-mix (75 mg) 1600; DL- $\alpha$-tocopherol acetate (0.168 mg) 20000; cholecalciferol (vitamin $\left.D_{3}\right)\left(10 \mathrm{mg}\right.$ ) 250; Menaquinone (vitamin $\mathrm{K}_{2}$ ): 50; sucrose, finely powdered, 971.4.

metabolic cages, and intestinal mineral absorption was evaluated (balance study). During this period dietary feed consumption was recorded and all faecal and urinary excretions were collected for each animal. Rats were killed under sodium pentobarbital anaesthesia $(40 \mathrm{mg} / \mathrm{kg}$, intraperitoneally). Tibia, liver and kidney were then removed, rinsed and frozen at $-20^{\circ} \mathrm{C}$ until analysis. Caecum and caecal contents were also sampled and weighed, and caecal content $\mathrm{pH}$ was determined.

\section{Sample treatment and analysis}

The faeces were freeze-dried and the wet and dry weights were determined. Urine volume was determined and $10 \mathrm{ml}$ urine was sampled and acidified with $0.2 \mathrm{ml}$ of $14 \mathrm{~mol}$ $\mathrm{HNO}_{3} / 1$. Adequate sub-samples of diet, faeces, urine, liver, one tibia and one kidney were dried overnight and then dryashed at $500^{\circ} \mathrm{C}$ for $10 \mathrm{~h}$. The ash was dissolved in $0.5 \mathrm{ml}$ of

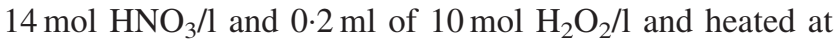
$110^{\circ}$ for $2 \mathrm{~h}$. The temperature was then increased to $130^{\circ} \mathrm{C}$ until the sample was dried. Then $5 \mathrm{ml}$ of $0 \cdot 14$ mol $\mathrm{HNO}_{3} / \mathrm{l}$ was added to every sample. In each case, an appropriate dilution with $0.14 \mathrm{~mol} \mathrm{HNO}_{3} / 1$ was performed before analysis. $\mathrm{Pb}$ concentrations were determined by inductively coupled plasma-mass spectrometry (ICP-MS). The mass spectrometer settings and plasma conditions were optimized with a solution of $10 \mu \mathrm{g} \mathrm{In} / \mathrm{l}$ and the instrument operating conditions were as follows: radio frequency generator $27 \cdot 12 \mathrm{MHz}$, forward radio frequency power $1350 \mathrm{~W}$, reflected radio frequency power $<3 \mathrm{~W}$, outer Ar flow rate $141 / \mathrm{min}$, intermediate Ar flow rate $0.71 / \mathrm{min}$, nebulizer $\mathrm{Ar}$ flow rate $0.76 \mathrm{l} / \mathrm{min}$, mass resolution $0.9 \mathrm{Da}$, at $10 \%$ of peak height. Data collection variables were as follows: total replicates per integration five, signal integration time per replicate $30 \mathrm{~s}$, dwell time per sweep $20.4 \mathrm{~s}$, scanning mode: peak hopping, five points per peak, sample uptake rate $0.6 \mathrm{ml} / \mathrm{min}$.

$\mathrm{Ca}, \mathrm{Mg}, \mathrm{Fe}, \mathrm{Zn}$ and $\mathrm{Cu}$ concentrations were determined by flame atomic absorption at wavelengths 422, 285, 248,
213.8 and $324.7 \mathrm{~nm}$ respectively using a Perkin Elmer 800 atomic absorption spectrometer (Perkin Elmer, St-Quentin en Yvelines, France).

Short-chain fatty acids were determined by GLC of portions of supernatant fractions of caecal contents (Demigné \& Rémésy, 1985).

\section{Calculations}

Relative apparent absorptions of $\mathrm{Pb}, \mathrm{Ca}, \mathrm{Mg}, \mathrm{Fe}, \mathrm{Zn}$ and $\mathrm{Cu}$ were calculated using the following equation:

$$
\begin{aligned}
& \text { Relative apparent absorption }(\%) \\
& =100 \times((\text { mineral intake } \\
& \quad-\text { mineral faecal excretion }) /(\text { mineral intake })) .
\end{aligned}
$$

Chemical mineral balance was determined as follows:

$$
\begin{aligned}
\text { Net balance }= & \text { mineral intake }-(\text { faecal excretion } \\
& + \text { urinary excretion }) .
\end{aligned}
$$

The caecal short-chain fatty acids contents $(\mu \mathrm{mol})$ were determined as caecal concentration $(\mu \mathrm{mol} / \mathrm{ml}) \times$ caecal water $(\mathrm{g})$.

\section{Statistical analysis}

The data are expressed as group means and SE. ANOVA was used to test for any significant differences among experimental groups. If the $F$ test was significant $(P<0.05)$, the Student-Newman-Keuls multiple comparisons test was used to determine the specific differences between group means. Parametric ANOVA was used when the SD were homogeneous. If not, the non-parametric ANOVA Kruskall-Wallis test was used. If this last test indicated a significant difference among experimental groups $(P<0.05)$, then the Mann-Whitney test was used to determine specific group differences. 


\section{Results}

Diet analysis indicated that the $\mathrm{Pb}$ levels of the control, and the $\mathrm{Pb}$-treated rats were 0.11 and $2.92 \mathrm{mg} \mathrm{Pb} / \mathrm{kg}$ diet. The target level was $3 \mathrm{mg} \mathrm{Pb} / \mathrm{kg}$ diet in the $\mathrm{Pb}$-treated groups. Food consumption and growth rate during $\mathrm{Pb}$ or dRGII treatments did not differ among the groups (Table 2).

\section{Effect of rhamnogalacturonan-II dimer addition on caecal fermentation parameters}

The addition of 2 or $6 \mathrm{~g} \mathrm{dRGII/kg} \mathrm{diet} \mathrm{did} \mathrm{not} \mathrm{influence}$ caecal fermentation parameters, whereas the addition of $18 \mathrm{~g}$ dRGII in the diet resulted in an enlargement of the caecum corresponding to an increase in the caecal content (Table 3). The caecal enlargement was accompanied by a significant decrease in the caecal content $\mathrm{pH}$ (Table 3). In parallel, there was a significant increase in the short-chain fatty acids pool in rats receiving $18 \mathrm{~g} \mathrm{dRGII/kg}$, especially acetate and propionate (about a twofold increase; Table 3).

\section{Effect of rhamnogalacturonan-II dimer addition on intestinal absorption and lead balance}

The relative faecal excretion of ingested $\mathrm{Pb}$ was significantly increased in groups receiving $\mathrm{dRGII}$ after $\mathrm{Pb}$ treatment when compared with the control or the Pb-treated group (Table 4). Among the groups receiving dRGII, the highest percentage of relative faecal excretion of ingested $\mathrm{Pb}$ was observed for groups receiving 6 or $18 \mathrm{~g} \mathrm{dRGII/kg}$. dRGII ingestion was accompanied by a significant increase in $\mathrm{Pb}$ intake. Nevertheless, the absorbed amount of $\mathrm{Pb}$ was closely similar for all the groups ( $\mu \mathrm{g} / \mathrm{d}$; Table 4$)$. As expected, the previous $\mathrm{Pb}$ treatment resulted in a high urinary excretion in the $\mathrm{Pb}$-treated group in comparison with the control group except for the group receiving $6 \mathrm{~g}$ $\mathrm{dRGII} / \mathrm{kg}$ (Table 4). In spite of the observed changes in $\mathrm{Pb}$ faecal and urinary excretions, $\mathrm{Pb}$ balance was unchanged in animals receiving dRGII (Table 4).

\section{Tissue retention of lead}

As expected, $\mathrm{Pb}$ treatment led to high accumulation of $\mathrm{Pb}$ in tibia and kidney. Three weeks after stopping $\mathrm{Pb}$ treatment, bone $\mathrm{Pb}$ concentrations had spontaneously decreased by about $50 \%$ for $\mathrm{Pb}$-treated rats compared with the baseline (Fig. 2). The addition of dRGII did not significantly accelerate the decrease in tibia $\mathrm{Pb}$ concentrations at the three doses used in the present experiment. Similarly, 3 weeks after stopping $\mathrm{Pb}$ treatment, kidney $\mathrm{Pb}$ concentrations had spontaneously decreased by about $80 \%$. Only the addition of $6 \mathrm{~g}$ dRGII/ $\mathrm{kg}$ was accompanied by a slight but significant decrease in kidney $\mathrm{Pb}$ concentration compared with the Pb-treated group (Fig. 2).

\section{Intestinal absorption and tissue retention of magnesium, calcium, zinc, copper and iron}

Neither $\mathrm{Pb}$ treatment nor dRGII addition had any significant effect on the absorbed amounts of certain essential minerals, which ranged from 155 to $195 \mathrm{mg} / \mathrm{d}, 3.7$ to $4.6 \mathrm{mg} / \mathrm{d}, 354$ to $465 \mu \mathrm{g} / \mathrm{d}, 114$ to $135 \mu \mathrm{g} / \mathrm{d}, 19$ to $31 \mu \mathrm{g} / \mathrm{d}$, for $\mathrm{Ca}, \mathrm{Mg}, \mathrm{Fe}, \mathrm{Zn}$ and $\mathrm{Cu}$ respectively. In addition, tissue concentrations of essential minerals and trace elements were determined and no significant changes were observed in the measured status indices (data not shown).

\section{Discussion}

In our previous work, a significant decrease in intestinal absorption and balance of $\mathrm{Pb}$ were observed when dRGII was given at $5 \mathrm{~g} / \mathrm{kg}$ diet simultaneously with $3 \mathrm{mg} \mathrm{Pb} / \mathrm{kg}$ diet (Tahiri et al. 2000). This observation suggests that dRGII probably acts by chelating both exogenous $\mathrm{Pb}$ (alimentary) and endogenous (biliary) $\mathrm{Pb}$ in the gastrointestinal tract, resulting in a decrease in their intestinal absorption. The low $\mathrm{Pb}$ balance suggested that dRGII might contribute to the detoxification of the body $\mathrm{Pb}$. Our experiment was designed to test this hypothesis.

Here, we investigated whether dRGII would reduce the

Table 2. Effect of 3 weeks of lead treatment followed by 3 weeks of rhamnogalacturonan-II dimer (dRGII) addition on food consumption and growth rate*

(Means and standard errors for ten rats per group)

\begin{tabular}{|c|c|c|c|c|c|c|c|c|c|c|}
\hline \multirow[b]{2}{*}{ Experimental diet... } & \multicolumn{2}{|c|}{ Control } & \multicolumn{2}{|c|}{$\mathrm{Pb}$-treated } & \multicolumn{2}{|c|}{$\begin{array}{c}\text { Pb-treated + } \\
2 \mathrm{~g} \mathrm{dRGII} / \mathrm{kg} \\
\text { diet }\end{array}$} & \multicolumn{2}{|c|}{$\begin{array}{c}\text { Pb-treated + } \\
6 \mathrm{~g} \mathrm{dRGII/kg} \\
\text { diet }\end{array}$} & \multicolumn{2}{|c|}{$\begin{array}{c}\text { Pb-treated + } \\
18 \mathrm{~g} \mathrm{dRGII} / \mathrm{kg} \\
\text { diet }\end{array}$} \\
\hline & Mean & $\overline{S E}$ & Mean & $\mathrm{SE}$ & Mean & $\mathrm{SE}$ & Mean & $\mathrm{SE}$ & Mean & $\overline{S E}$ \\
\hline $\begin{array}{l}\text { Food consumption at day } 0 \\
(\mathrm{~g} / \mathrm{d})\end{array}$ & $17 \cdot 46^{a}$ & 0.21 & $17 \cdot 99^{a}$ & 0.35 & $17 \cdot 77^{\mathrm{a}}$ & 0.18 & $17 \cdot 35^{a}$ & 0.23 & $18 \cdot 51^{a}$ & 0.31 \\
\hline $\begin{array}{l}\text { Food consumption at day } 21 \text {, } \\
\text { after } P b \text { treatment }(\mathrm{g} / \mathrm{d})\end{array}$ & $19 \cdot 97^{\mathrm{a}}$ & 0.68 & $20 \cdot 18^{a}$ & 0.84 & $20 \cdot 58^{a}$ & 0.59 & $21 \cdot 35^{\mathrm{a}}$ & $1 \cdot 12$ & $20 \cdot 98^{a}$ & 0.48 \\
\hline $\begin{array}{l}\text { Food consumption at day } 35 \\
\text { after dRGII treatment }(\mathrm{g} / \mathrm{d})\end{array}$ & $20 \cdot 84^{a}$ & 0.62 & $24.09^{a}$ & 1.68 & $22 \cdot 65^{\mathrm{a}}$ & 1.08 & $22 \cdot 52^{\mathrm{a}}$ & 0.98 & $22 \cdot 89^{\mathrm{a}}$ & 0.82 \\
\hline $\begin{array}{l}\text { Growth rate between day } 0 \\
\text { and day } 21(\mathrm{~g} / \mathrm{d})\end{array}$ & $7 \cdot 13^{\mathrm{a}}$ & 0.24 & $7 \cdot 32^{\mathrm{a}}$ & 0.24 & $7 \cdot 54^{\mathrm{a}}$ & 0.25 & $7 \cdot 21^{a}$ & 0.26 & $7 \cdot 49^{a}$ & 0.17 \\
\hline $\begin{array}{l}\text { Growth rate between day } 21 \\
\text { and day } 35(\mathrm{~g} / \mathrm{d})\end{array}$ & $4.03^{a}$ & 0.26 & $4 \cdot 26^{a}$ & 0.19 & $4 \cdot 28^{a}$ & 0.22 & $4 \cdot 18^{a}$ & 0.14 & $4.55^{\mathrm{a}}$ & 0.25 \\
\hline
\end{tabular}

${ }^{a}$ Mean values within a row with unlike superscript letters were significantly different $(P<0.05)$.

* For details of diets and procedures, see Table 1 and pp. 48-49. 
Table 3. Effect of 3 weeks of rhamnogalacturonan-II dimer (dRGII) addition on fermentation parameters*

(Means and standard errors for ten rats per group)

\begin{tabular}{|c|c|c|c|c|c|c|c|c|c|c|}
\hline \multirow[b]{2}{*}{ Experimental diet... } & \multicolumn{2}{|c|}{ Control } & \multicolumn{2}{|c|}{ Pb-treated } & \multicolumn{2}{|c|}{$\begin{array}{l}\text { Pb-treated }+2 \mathrm{~g} \\
\mathrm{dRG} / \mathrm{l} / \mathrm{kg} \text { diet }\end{array}$} & \multicolumn{2}{|c|}{$\begin{array}{l}\text { Pb-treated }+6 \mathrm{~g} \\
\mathrm{dRG} / \mathrm{kg} \text { diet }\end{array}$} & \multicolumn{2}{|c|}{$\begin{array}{c}\text { Pb-treated }+18 \mathrm{~g} \\
\text { dRGII } / \mathrm{kg} \text { diet }\end{array}$} \\
\hline & Mean & SE & Mean & $\mathrm{SE}$ & Mean & SE & Mean & SE & Mean & SE \\
\hline Caecal content $(\mathrm{g})$ & $2 \cdot 27^{a}$ & 0.23 & $2 \cdot 17^{\mathrm{a}}$ & 0.13 & $2 \cdot 20^{\mathrm{a}}$ & 0.13 & $2 \cdot 19^{\mathrm{a}}$ & 0.16 & $2 \cdot 82^{b}$ & $0 \cdot 13$ \\
\hline Caecal content pH & $7 \cdot 13^{a}$ & 0.04 & $7 \cdot 29^{b}$ & 0.04 & $7 \cdot 16^{a b}$ & 0.05 & $7 \cdot 05^{\mathrm{ab}}$ & 0.14 & $6 \cdot 93^{c}$ & 0.06 \\
\hline Acetate (nmol/caecum) & $127 \cdot 3^{a}$ & 21.0 & $112 \cdot 6^{\mathrm{a}}$ & $9 \cdot 3$ & $110 \cdot 3^{a}$ & $5 \cdot 3$ & $112 \cdot 3^{a}$ & 8.4 & $184 \cdot 6^{\mathrm{b}}$ & $9 \cdot 4$ \\
\hline Propionate (nmol/caecum) & $45 \cdot 3^{\mathrm{a}}$ & 8.2 & $38 \cdot 5^{\mathrm{a}}$ & $3 \cdot 4$ & $35 \cdot 1^{\mathrm{a}}$ & 1.4 & $38 \cdot 0^{\mathrm{a}}$ & 3.1 & $70 \cdot 2^{b}$ & $4 \cdot 1$ \\
\hline Butyrate (nmol/caecum) & $19 \cdot 4^{\mathrm{a}}$ & $2 \cdot 1$ & $20 \cdot 8^{a}$ & 1.9 & $18 \cdot 0^{\mathrm{a}}$ & $1 \cdot 1$ & $19 \cdot 8^{\mathrm{a}}$ & $5 \cdot 2$ & $23 \cdot 4^{a}$ & 3.0 \\
\hline
\end{tabular}

a,b,c Mean values within a row with unlike superscript letters were significantly different $(P<0.05)$.

${ }^{*}$ For details of diets and procedures, see Table 1 and pp. 48-49.

body burden of $\mathrm{Pb}$ in rats exposed for 3 weeks to $\mathrm{Pb}$ acetate in feed. We gave three different doses of dRGII for 3 weeks after the end of dietary $\mathrm{Pb}$ exposure. We started the $\mathrm{Pb}$ balance evaluation during the last week, when there was no more unabsorbed dietary $\mathrm{Pb}$ in the gastrointestinal tract, and the only $\mathrm{Pb}$ excreted in faeces, 2 weeks after the end of exposure, is $\mathrm{Pb}$ eliminated through the bile, which comes from the endogenous accumulation of $\mathrm{Pb}$ in the body.

The main result of the present study was that dRGII did not contribute to the detoxification of body $\mathrm{Pb}$ when given after chronic exposure to $\mathrm{Pb}$. Intestinal absorption, balance and $\mathrm{Pb}$ tissue status remained similar at the end of the experiment in rats receiving the different doses of dRGII $(0$, $2,6,18 \mathrm{~g} / \mathrm{kg}$ of diet). The hypothesis that dRGII may accelerate $\mathrm{Pb}$ detoxification was not confirmed in our conditions and study design. Even so, when dRGII was given concomitantly with $\mathrm{Pb}$, the intestinal absorption was dramatically depressed (Tahiri et al. 2000). Hence dRGII seems to contribute mainly to detoxifying alimentary $\mathrm{Pb}$ (exogenous), but probably not that in body stores (endogenous).

Pectin binding of heavy metal ions has recently been evaluated in aqueous solution by Kartel et al. (1999). They showed that the pectins studied had very high binding affinities to $\mathrm{Pb}^{2+}$. The action of pectins on heavy metal absorption has already been investigated. Most of the investigations on the action of pectin on $\mathrm{Pb}$ poisoning using animal models have shown a beneficial effect of pectin in $\mathrm{Pb}$ detoxification (Niculescu et al. 1968; Bondarev et al. 1979; Ivanov et al. 1997; Kushneva \& Koltunova, 1997. However, Wapnir et al. (1980) failed to show any difference in intestinal $\mathrm{Pb}$ absorption or in urinary excretion of $\mathrm{Pb}$ after pectin feeding in rats. Other plant fibres, such as cellulose and glucomannan, have also been tested for their effect on $\mathrm{Pb}$ absorption in rats (Hayashi et al. 1991). The mechanisms involved in this effect are an increased $\mathrm{Pb}$ faecal and/or urinary excretion. According to Niculescu et al. (1968) and Macholz et al. (1989) both excretions are increased in rats and human subjects fed pectins. The increased plumburia in this type of experiment (pectin and $\mathrm{Pb}$ taken orally) suggests that pectin components may be absorbed and reach the blood to complex $\mathrm{Pb}$, which will be excreted in the urine. The absorption of oligo-galacturonic acids has been shown to occur in rats after pectin feeding. According to Anger et al. (1994) when injected into the caecum of rats, 9 to $45 \%$ oligogalacturonic acids are recovered in the urine within $16 \mathrm{~h}$. This property is probably closely linked to the structure of the pectin considered. The data from our experiment showed that $\mathrm{Pb}$ urinary excretion was independent of the level of dRGII supplied in the diets. Therefore, dRGII cannot complex $\mathrm{Pb}$ in blood and promotes its elimination through urinary excretion. Consequently, dRGII seems to exert its effect mainly through an increased faecal excretion of the $\mathrm{Pb}$ present in the diet.

Table 4. Effect of rhamnogalacturonan-II dimer (dRGII) addition on the apparent intestinal absorption and chemical balance of lead in rats* (Means and standard errors for ten rats per group)

\begin{tabular}{|c|c|c|c|c|c|c|c|c|c|c|}
\hline \multirow[b]{2}{*}{ Experimental diet... } & \multicolumn{2}{|c|}{ Control } & \multicolumn{2}{|c|}{ Pb-treated } & \multicolumn{2}{|c|}{$\begin{array}{l}\text { Pb-treated }+2 \mathrm{~g} \\
\mathrm{dRGII} / \mathrm{kg} \text { diet }\end{array}$} & \multicolumn{2}{|c|}{$\begin{array}{l}\text { Pb-treated }+6 \mathrm{~g} \\
\text { dRGII/kg diet }\end{array}$} & \multicolumn{2}{|c|}{$\begin{array}{c}\text { Pb-treated + } \\
18 \mathrm{~g} \text { dRGII } / \mathrm{kg} \\
\text { diet }\end{array}$} \\
\hline & Mean & SE & Mean & $\mathrm{SE}$ & Mean & SE & Mean & SE & Mean & SE \\
\hline Food consumption $(\mathrm{g} / \mathrm{d})$ & $17 \cdot 84$ & 0.75 & 19.93 & 0.34 & $18 \cdot 29$ & 0.74 & 18.95 & 0.34 & $18 \cdot 27$ & 0.51 \\
\hline $\mathrm{Pb}$ intake $(\mu \mathrm{g} / \mathrm{d})$ & $2 \cdot 00^{\mathrm{a}}$ & 0.08 & $2 \cdot 23^{\mathrm{b}}$ & 0.04 & $3.01^{\mathrm{c}}$ & $0 \cdot 12$ & $5 \cdot 48^{d}$ & $0 \cdot 10$ & $12 \cdot 33^{\mathrm{e}}$ & 0.34 \\
\hline Faecal $\mathrm{Pb}$ excretion $(\mu \mathrm{g} / \mathrm{d})$ & $1 \cdot 17^{\mathrm{a}}$ & 0.07 & $1.45^{\mathrm{b}}$ & 0.05 & $2 \cdot 43^{c}$ & 0.13 & $4 \cdot 86^{d}$ & 0.14 & $11 \cdot 42^{\mathrm{e}}$ & 0.31 \\
\hline $\begin{array}{l}\text { Relative faecal excretion of ingested } \\
\mathrm{Pb}(\%)\end{array}$ & $58 \cdot 80^{\mathrm{a}}$ & $2 \cdot 34$ & $65 \cdot 29^{\mathrm{a}}$ & $2 \cdot 10$ & $80 \cdot 73^{\mathrm{b}}$ & $3 \cdot 10$ & $88 \cdot 77^{\mathrm{C}}$ & 2.04 & $92 \cdot 79^{\mathrm{C}}$ & 1.92 \\
\hline Apparent absorption of $\mathrm{Pb}(\%)$ & $41 \cdot 20^{\mathrm{a}}$ & $2 \cdot 34$ & $34 \cdot 71^{\mathrm{a}}$ & $2 \cdot 10$ & $19 \cdot 27^{b}$ & $3 \cdot 10$ & $11 \cdot 23^{\mathrm{C}}$ & $2 \cdot 04$ & $7 \cdot 21^{\mathrm{c}}$ & 1.92 \\
\hline Apparent absorption of $\mathrm{Pb}(\mu \mathrm{g} / \mathrm{d})$ & $0.83^{\mathrm{a}}$ & 0.06 & $0.77^{\mathrm{a}}$ & 0.05 & $0.58^{\mathrm{a}}$ & $0 \cdot 10$ & $0.62^{\mathrm{a}}$ & $0 \cdot 12$ & $0.91^{\mathrm{a}}$ & 0.26 \\
\hline Urinary $\mathrm{Pb}$ excretion $(\mu \mathrm{g} / \mathrm{d})$ & $0.030^{\mathrm{a}}$ & 0.006 & $0.062^{\mathrm{cb}}$ & 0.005 & $0.066^{\mathrm{cb}}$ & 0.006 & $0.047^{a b}$ & 0.005 & $0.070^{c}$ & 0.008 \\
\hline $\mathrm{Pb}$ balance $(\mu \mathrm{g} / \mathrm{d})$ & $0 \cdot 764^{\mathrm{a}}$ & 0.188 & $0.715^{\mathrm{a}}$ & 0.169 & $0.516^{a}$ & 0.312 & $0.570^{a}$ & 0.362 & $0 \cdot 841^{a}$ & 0.827 \\
\hline
\end{tabular}

a,b,c,d,e Mean values within a row with unlike superscript letters were significantly different $(P<0.05)$.

${ }^{*}$ For details of diets and procedures, see Table 1 and pp. 48-49. 

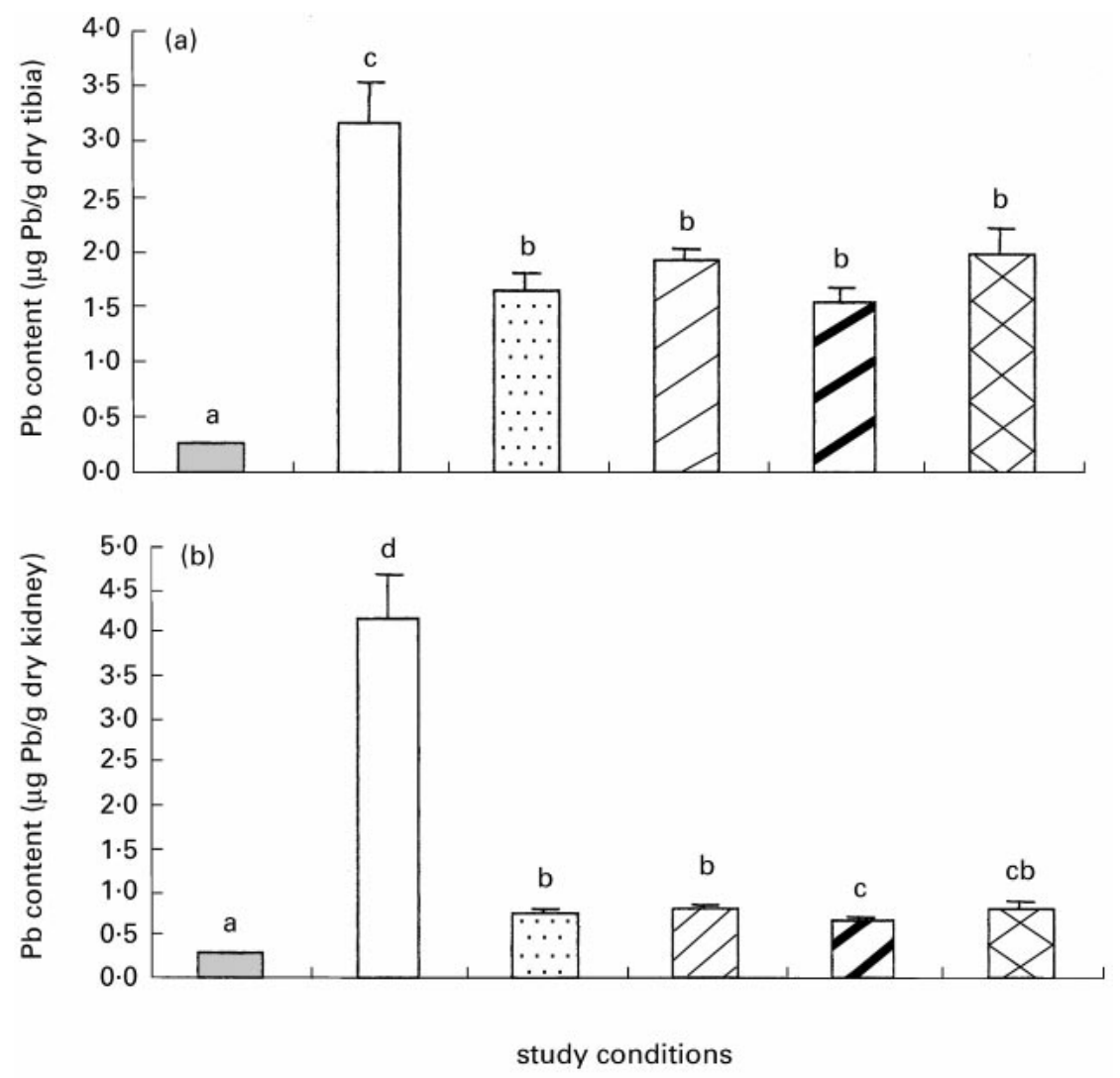

Fig. 2. Effect of lead administration followed by rhamnogalacturonan-II dimer (dRGII) administration on tibia (a) and kidney (b) lead levels in the rat. The control group ( $\square$ ) received a standard diet. Baseline $(\square)$ was a group receiving $3 \mathrm{mg}$ lead $/ \mathrm{kg}$ for 3 weeks after which animals were killed to serve as baseline for lead status. The lead-treated group (粯) received $3 \mathrm{mg}$ lead $/ \mathrm{kg}$ for 3 weeks and then a standard diet for 3 weeks. The

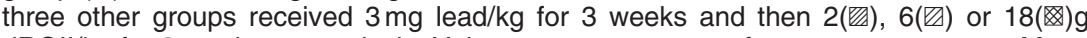
$\mathrm{dRGII/kg}$ for 3 weeks respectively. Values are group means for ten rats per group. Mean values for treatments with unlike letters were significantly different, $P<0.05$. Standard errors are represented by vertical bars.

RGII is a low molecular weight pectic polysaccharide $(5000 \mathrm{D})$, present in the cell walls of growing plants, from which RGII can be released by an endo- $\alpha-1,4$-polygalacturonase in a dimer from (O'Neill et al. 1990. dRGII has a strong ability to complex $\mathrm{Pb}$ (Ishii et al. 1999). Therefore, during the isolation procedure, the small amounts of $\mathrm{Pb}$ present in the environment may bind strongly to dRGII in the present study. The addition of dRGII to the animal diet was thus accompanied by a slight increase in $\mathrm{Pb}$ intake of about $30 \mu \mathrm{g} / \mathrm{g}$ dRGII added to the diet. However, when complexed to dRGII, $\mathrm{Pb}$ is not available for intestinal absorption. For the faecal excretion of $\mathrm{Pb}$, the results of our study are consistent with our previous work (Tahiri et al. 2000). Quantities of absorbed $\mathrm{Pb}$ and balance were equivalent between animals receiving the supplemental $\mathrm{Pb}$ present in the added dRGII and controls whose diet was nearly devoid of $\mathrm{Pb}$.

dRGII possesses a high capacity to bind certain minerals. The cations that bond to dRGII have some common properties: a valency of ${ }^{2+}$ or ${ }^{3+}$; a crystal ionic radius $>0.95 \AA$; an electronic configuration with an incompletely filled sub-shell; a low energy of ionization; an affinity for O-donor ligands (O'Neill et al. 1996). Many metals, in particular the toxic metals $\mathrm{Pb}^{2+}, \mathrm{Ba}^{2+}, \mathrm{Sr}^{2+}, \mathrm{La}^{3+}, \mathrm{Eu}^{3+}$, $\mathrm{Ce}^{3+}, \mathrm{Pr}^{3+}$ and $\mathrm{Nd}^{3+}$, fulfill these requirements and so are strongly chelated to dRGII. However, these characteristics of dRGII exclude the chelating of essential cations such as $\mathrm{Ca}^{2+}, \mathrm{Mg}^{2+}, \mathrm{Fe}^{2+}, \mathrm{Zn}^{2+}$ and $\mathrm{Cu}^{2+}$. In vitro, the formation of $\mathrm{dRGII}$ from its monomer necessitates the presence of boric acid. The presence of an appropriate cation can also accelerate the formation of the dimer, which then strongly binds that cation, for example $\mathrm{Pb}$. It is well known that $\mathrm{dRGII}$, once formed, can bind added $\mathrm{Pb}$, and that this depends on environmental conditions, e.g. $\mathrm{pH}$. The optimal $\mathrm{pH}$ for this binding is between 3 and 5 . We can speculate that dRGII can bind $\mathrm{Pb}$ in the gastric compartment where the gastric $\mathrm{pH}$ may be favourable. This can probably explain the observed inhibitory effect of dRGII on intestinal $\mathrm{Pb}$ absorption in our earlier work (Tahiri et al. 2000). On the contrary, it is possible that dRGII is unable to chelate $\mathrm{Pb}$ in the intestinal section where the $\mathrm{pH}$ is higher than 6. Bile $\mathrm{Pb}$ excretion is the main pathway for elimination of body $\mathrm{Pb}$ (Conrad \& Barton, 1978; Alexander et al. 1986). It is well known that $\mathrm{Pb}$ undergoes enterohepatic re-circulation. In a previous study ( $\mathrm{M}$ Tahiri, $\mathrm{T}$ Doco and $\mathrm{C}$ Coudray, unpublished results), we showed that the daily administration 
of $20 \mu \mathrm{g} \mathrm{Pb}$ intra-peritoneally in rats resulted in very high $\mathrm{Pb}$ excretion through the bile (more than two-thirds of the administered dose). Because of this, we expected dRGII to increase $\mathrm{Pb}$ excretion only if the $\mathrm{Pb}$ excreted through the bile could bind to dRGII in the intestine. It is highly likely that this $\mathrm{Pb}$ is not bound by dRGII in the upstream end of the intestine in the present study. This may at least partly explain the failure of dRGII to contribute to $\mathrm{Pb}$ elimination after chronic $\mathrm{Pb}$ exposure in rats.

The bioavailability of metals bound to fibres may depend on the ease of release of metals in the gut as well as on the extent to which the fibre is fermented in the colon (Ou et al. 1999). dRGII is a fermentable pectic polysaccharide that undergoes complete fermentation by the microflora in the large intestine. In fact, dRGII was not detectable in the rat faeces in the present study (data not shown). At the highest dose given in the present experiment (18 $\mathrm{g}$ dRGII/ $\mathrm{kg}$ diet), the fermentation of dRGII results in a significant increase in short-chain fatty acid production in the rat caecum. This production was similar to that of inulin which is considered a well-fermented dietary fibre (data not shown). Fermentation may result in a dissociation and release, in the large intestine, of the small amount of Pb complexed to dRGII. Moreover, the short-chain fatty acid production resulted in a significant decrease in caecal $\mathrm{pH}$, which in turn contributes to a better solubilization of $\mathrm{Pb}$. This effect of fermentation is known to improve the adsorption of other minerals such as Ca and Mg (Demigné et al. 1995; Younes et al. 1996). A possible increase in intestinal absorption of $\mathrm{Pb}$ might thus occur through the para-cellular pathway in the colon when this fermentation is high. $\mathrm{Pb}$ is primarily absorbed in the small intestine and particularly in the duodenum and via the trans-cellular pathway (Diamond et al. 1998). Although the main site of intestinal absorption of $\mathrm{Pb}$ is located in the small intestine, an increased absorption in the lower parts of the intestine may increase the overall intestinal absorption of $\mathrm{Pb}$. A negative effect of dRGII on $\mathrm{Pb}$ absorption is exerted since very small amounts of dRGII ( $0.5 \mathrm{~g} / \mathrm{kg}$ diet $)$, and a significant effect was observed for the dose $5 \mathrm{~g}$ $\mathrm{dRGII/kg}$ diet (Tahiri et al. 2000). In our experiment, we again observed a significant reduction effect on $\mathrm{Pb}$ kidney level at the dose $6 \mathrm{~g} \mathrm{dRGII/kg} \mathrm{diet,} \mathrm{but} \mathrm{this} \mathrm{effect}$ disappeared at the dose $18 \mathrm{~g} \mathrm{dRGII} / \mathrm{kg}$. It can be deduced that fermentation may be active at more than $10 \mathrm{~g} \mathrm{dRGII} / \mathrm{kg}$, where the possible contribution of $\mathrm{Pb}$ absorption in the colon may be significant and should be taken into account.

In conclusion, our findings show that dietary $\mathrm{Pb}$, when bound to dRGII, is essentially unavailable for intestinal absorption. Consequently, $\mathrm{Pb}$ present in the form of dRGII chelates in fruits, vegetables and fruit juices is probably not available for absorption. However, our results show also that the addition of dRGII after $\mathrm{Pb}$ exposure was not effective in assisting the process of $\mathrm{Pb}$ detoxification in rats. Therefore, although the presence of dRGII in food may have a preventive action on $\mathrm{Pb}$ absorption, it seems unable to act as a curative agent in $\mathrm{Pb}$ poisoning. Studies with human subjects are still needed to confirm these results in rats.

\section{Acknowledgements}

The authors thank the French Ministry of National
Education, Research and Technology (No. 99 P 0544) and the French National Institute for Agronomic Research (INRA) for their financial support, and Claudine Lab and Elyett Gueux for their technical assistance.

\section{References}

Alexander J, Aaseth J \& Mikalsen A (1986) Excretion of lead in rat bile - the role of glutathione. Acta Pharmacologica et Toxicologica (Copenhagen) 59, 486-489.

Anger H, Walzel E \& Kahrmann B (1994) About the absorption of oligogalacturonides from caecum of rats. FASEB Journal 8, A152.

Bondarev GI, Anisova AA, Alekseeva TE \& Syzrantsev IK (1979) Evaluation of a pectin with a low degree of esterification as a prophylactic agent in lead poisoning. Voprosy Pitaniya 2, 65-67.

Chisolm JJ (2000) Safety and efficacy of meso-2,3-dimercaptosuccinic acid (DMSA) in children with elevated blood lead concentrations. Journal of Toxicology, Clinical Toxicology 38, $365-375$.

Conrad ME \& Barton JC (1978) Factors affecting the absorption and excretion of lead in the rat. Gastroenterology 74, 731-740.

Demigné C, Levrat MA, Younes H \& Remesy C (1995) Interactions between large intestine fermentation and dietary calcium. European Journal of Clinical Nutrition 49, S235-S238.

Demigné C \& Rémésy C (1985) Stimulation of absorption of volatile fatty acids and minerals in the cecum of rats adapted to a very high fiber diet. Journal of Nutrition 115, 53-60.

Diamond GL, Goodrum PE, Felter SP \& Ruoff WL (1998) Gastrointestinal absorption of metals. Drug and Chemical Toxicology 21, 223-251.

Hayashi M, Simazaki Y, Kamata S \& Kakiichi N (1991) The effect of cellulose and glucomannan on the absorption of lead in rats. Nippon Koshu Eisei Zasshi 38, 553-559.

Ishii T, Matsunaga T, Pellerin P, O’Neill MA, Darvill A \& Albersheim P (1999) The plant cell wall polysaccharide rhamnogalacturonan II self-assembles into a covalently crosslinked dimer. Journal of Biological Chemistry 274, $13098-13104$.

Ivanov AA, Kalistratova VS, Kolesnov AI, Koltunova IG, Kochetkova AA, Kushneva VS, Kuz'mina TD, Mal'tsev VN, Stavrakova NM, Ulanova AM \& Nisimov PG (1997) Effects of pectins with different levels of esterification and food additive Medetopect on colon microflora in rats after lead poisoning and lesions by radioactive isotopes. Voprosy Pitaniya 2, 15-18.

Kartel MT, Kupchik LA \& Veisov BK (1999) Evaluation of pectin binding of heavy metal ions in aqueous solutions. Chemosphere 38, 2591-2596.

Kushneva VS \& Koltunova IG (1997) Pectins of various degrees of esterification and pectin-containing preparation "Medetopect" as promoters of lead elimination (experimental data). Med $\mathrm{Tr}$ Prom Ekol 7, 27-31.

Macholz R, Walzel E \& Kujawa M (1989) Influence of pectin on the availability of toxic and essential minerals in lead exposed persons. Chemical and Biological Aspects 72, 293-295.

Markowitz M (2000) Lead poisoning: a disease for the next millennium. Review. Current Problems in Pediatrics 30, 62-70.

Niculescu T, Rafaila E, Eremia R \& Balasa E (1968) Investigations on the action of pectin in experimental lead poisoning. Igiena 17, 3-8.

O'Neill MA, Albersheim P \& Daryimm AG (1990) The pectic polysaccharides of primary cell walls. In Methods in Plant Biochemistry, pp. 415-441 [PM Dey, editor]. London: Academic Press. 
O’Neill MA, Warrenfeltz D, Kates K, Pellerin P, Doco T, Darvill AG \& Albersheim P (1996) Rhamnogalacturonan-II, a pectic polysaccharide in the walls of growing plant cell, forms a dimer that is covalently cross-linked by a borate ester. In vitro conditions for the formation and hydrolysis of the dimer. Journal of Biological Chemistry 271, 22923-22930.

Ou S, Gao K \& Li Y (1999) An in vitro study of wheat bran binding capacity for $\mathrm{Hg}, \mathrm{Cd}$, and $\mathrm{Pb}$. Journal of Agricultural and Food Chemistry 47, 4714-4717.

Pellerin P, Doco T, Vidal S, Williams P, Brillouet JM \& O'Neil MA (1996) Structural characterization of red wine rhamnogalacturonan II. Carbohydrates Research 290, 183-197.

Reeves PG, Nielsen FH \& Fahey GC (1993) AIN-93 purified diets for laboratory rodents: final report of the American Institute of Nutrition Ad Hoc writing committee on the reformulation of the AIN-76A rodent diet. Journal of Nutrition 123, 1939-1951.

Rose HE \& Quarterman J (1987) Dietary fibers and heavy metal retention in the rat. Environmental Research 42, 166-175.

Silbergeld EK (1996) Lead poisoning: the implications of current biomedical knowledge for public policy. Review. Md Medical Journal 45, 209-217.

Tahiri M, Pellerin P, Tressol JC, Doco T, Pepin D, Rayssiguier Y \& Coudray C (2000) The rhamnogalacturonan-II dimer decreases intestinal absorption and tissue accumulation of lead in rats. Journal of Nutrition 130, 249-253.

Thomas DJ \& Chisolm J (1986) Lead, zinc and copper decorporation during calcium disodium ethylenediamine tetraacetate treatment of lead-poisoned children. Journal of Pharmacology and Experimental Therapeutics 239, 829-835.

Wapnir RA, Moak SA \& Lifshitz F (1980) Reduction of lead toxicity on the kidney and the small intestinal mucosa by kaolin and pectin in the diet. American Journal of Clinical Nutrition 33, 2303-2310.

Younes H, Demigné C \& Remesy C (1996) Acidic fermentation in the caecum increases absorption of calcium and magnesium in the large intestine of the rat. British Journal of Nutrition 75, $301-314$. 